\section{An Induced Mutation for Genie Male Sterility in Common Bean}

\author{
Mark J. Bassett ${ }^{1}$ and Mathias J. Silbernage ${ }^{2}$ \\ Horticultural Sciences Department, Institute of Food and Agricultural \\ Sciences, University of Florida, Gainesville, FL 32611
}

Additional index words. Phaseolus vulgaris, inheritance

\begin{abstract}
Dry seed of the common bean (Phaseolus vulgaris L.) breeding line S-593 was treated with $200 \mathrm{~Gy}$ of gamma radiation, and $M_{2}$ seed was produced. The seed was planted at Prosser, Wash., and selection was made for plants with greatly reduced seed set. The inheritance of one of the selections for possible male sterility mutation was studied in $F_{2}, F_{3}$, and backcross generations. This character is controlled by a single recessive gene, for which the symbol $m s-1$ is proposed. Plants carrying $m s-l / m s-1$ produce well-filled pods after manual pollination with pollen from normal plants, but produce no seed when protected from insect pollination in greenhouse and field environments. Uses for this mutant are discussed.
\end{abstract}

A stable genie male sterility of common bean was reported by Mutschler and Bliss (1980), but that source has a complex inheritance that is not properly understood (Ashraf and Bassett, 1986; Bassett, 1989). Also, that material is not available for use by other investigators and bean breeders. Subsequently, Wyatt (1984) reported an indehiscent anther character (ian) (Bassett, 1989) that prevents pollen from being shed. However, the ian mutant is somewhat "leaky" and allows a small percentage of self-pollination. Thus, ian is not useful for all applications that are desired for a true male-sterile mutant. Recently, Bassett (1991) reported a mutant at the spindly branch locus (Bassett, 1990) that is pleiotropic for genie male sterility, providing a useful marker for male sterility that can be distinguished from fertile plants in the field, both before flowering and at full senescence. What is still lacking is a simply inherited genie male sterility that is not pleiotropic for other changes in plant morphology.

This paper presents evidence that such a male-sterile mutant was induced in common bean and has potential for exploitation in basic research and applied breeding programs.

Florida dry bean breeding line 5-593 was selected as parental material, because it is being used as the recurrent parent in a backcross breeding project to convert numerous marker genes of common bean to a common genetic background. Line 5-593 has determinate habit, purple flowers, and small, shiny black seed. Dry seeds of S-593 were treated with 100 or 200 Gy of gamma radiation using

Received for publication 2 Dec. 1991. Accepted for publication 11 May 1992. Florida Agr. Expt. Sta. Journal Series no. R-01916. The cost of publishing this paper was defrayed in part by the payment of page charges. Under postal regulations, this paper therefore must be hereby marked $a d$ vertisement solely to indicate this fact.

${ }^{\text {'Professor. }}$

${ }^{2}$ U.S. Dept. of Agriculture, Agricultural Research Service, Irrigated Agriculture Research and Education Center, Rt. 2, Box 2953A, Prosser, WA 99350. a Gammator Model M with a Cs 137 source (Radiation Machinery Corp., Parsippany, N.J.). The $M_{1}$ generation was produced at Gainesville, Fla., in 1987.

The $\mathrm{M}_{2}$ cannot be grown advantageously at Gainesville because of an abundance of bumblebees, which are very efficient pollinators of common bean. If there are any $\mathrm{M}_{2}$ plants that segregate for male sterility, they will be so thoroughly and quickly pollinated by bumblebees that they could not be distinguished from fertile plants either by their lack of seed set or by the lateness of their maturity. The plots could have been grown under netting, but the population size required for success in this project was too large to permit production at reasonable cost under netting. Therefore, the $\mathbf{M}_{2}$ was produced in the desert regions of the western United States at the Irrigated Agriculture Research and Education Center, Prosser, Wash., where there is a scarcity of bumblebees and other insect pollinators. More than $30,000 \mathrm{M}_{2}$ plants were grown at Prosser in 1988, and $» 90 \%$ of these had been exposed to $100 \mathrm{~Gy}$. After most of the plants had finished flowering, the plots were searched for plants that were still flowering and had set a few (sometimes only one or two) pods. Eight such plants were selected, and the seeds were sent to Gainesville for genetic investigation.

Inheritance tests. Two plants $\left(\mathrm{F}_{1}\right)$ from each of the eight selections made at Prosser were grown in the greenhouse at Gainesville in Fall 1989. One of the selections was labeled MS-3, and its two plants appeared to have completely normal fertility and seed set. In Spring 1990, separate $\left(\mathrm{F}_{2}\right)$ progenies from these two plants were grown in the field under shadecloth netting. After flowering had continued for $\approx 2$ weeks, numerous flowers were examined for pollen shed on several plants showing no evidence of pod set. Within these two plots (0-684 and 0-685), several plants were selected that shed no pollen and were hand-pollinated with pollen from 5-593. Pods with full seed set $\left(\mathrm{F}_{1}\right)$ were produced from each attempted pollination. The two plots (0-684 and 0-685) were allowed to grow un- der netting until the majority of the plants were starting to turn yellow due to senescence. The netting was removed, and data were taken on the number of plants with mature pods (fertile) and the number of plants that were still flowering with no pod set (sterile). When all fertile plants were fully mature and senescent, seeds were harvested from 27 plants from plot $0-685$ for use in $\mathrm{F}_{3}$ progeny tests the following year.

Backcross and allelism tests. Remnant seeds from plot 0-685 and seeds from the above $F_{1}$ (MS-3 steriles $\times 5$-593) were planted in the greenhouse in Fall 1990. Segregants from $0-685$ seeds that failed to shed any pollen were crossed with pollen from the $F_{1}$ plants to produce backcross seed. Material segregating for the spindly branch, malesterile character $s b^{\mathrm{ms}}$ (Bassett, 1991) was also planted in the greenhouse. Plants showing $s b^{\text {ms }}$ were crossed with pollen from the above $\mathrm{F}_{1}$ plants to produce seeds for an allelism test between $s b^{\mathrm{ms}}$ and the MS-3 putative malesterile character. Also, seeds were harvested from the $\mathrm{F}_{1}$ plants to obtain $\mathrm{BC}_{1}-\mathrm{F}_{2}$ seed (MS3 into the 5-593 background). In Spring 1991 seeds were planted in the field for the backcross test, the $\mathrm{BC}_{1}-\mathrm{F}_{2}$ test, and the $\mathrm{F}_{3}$ progeny tests from normal $\mathrm{F}_{2}$ plants. All these plots were grown under netting until the onset of senescence, when the netting was re-

\begin{tabular}{|c|c|c|c|c|}
\hline \multirow[b]{2}{*}{ Plot no. } & \multicolumn{2}{|c|}{$\begin{array}{l}\text { Phenotypic } \\
\text { classes }\end{array}$} & \multirow{2}{*}{$\begin{array}{c}\chi^{2} \\
(3: 1)\end{array}$} & \multirow[b]{2}{*}{$P$ value } \\
\hline & Fertile & Sterile & & \\
\hline $0-684$ & 36 & 14 & 0.24 & 0.62 \\
\hline \multirow[t]{2}{*}{$0-685$} & 33 & 14 & 0.57 & 0.45 \\
\hline & 69 & 28 & 0.77 & 0.38 \\
\hline
\end{tabular}

Table 2. Segregation in a backcross test derived from 0-685 (remnant seed) $m s-l / m s l \times \mathrm{F}_{1}$ $(M s-1 / m s-1$ from $0-685 \times 5-593)$ and in the $\mathrm{BC}_{1}-\mathrm{F}_{2}$ of $m s-1$ into 5-593, where $m s-1$ is a symbol for a male sterility mutant of common bean.

\begin{tabular}{lcccccc}
\hline \hline & \multicolumn{3}{c}{$\begin{array}{c}\text { Phenotypic } \\
\text { classes }\end{array}$} & & & \\
& R a t i $\boldsymbol{Q}^{2}$ & \\
\cline { 2 - 5 } Generation & Fertile & Sterile & tested value & $P$ value \\
\hline $\mathrm{BC}$ test & 68 & 55 & $1: 1$ & 1.37 & 0.24 \\
$\mathrm{BC}_{1}-\mathrm{F}_{2}$ & 28 & 10 & $3: 1$ & 0.035 & 0.85 \\
\hline
\end{tabular}

Table $3 . \mathrm{F}_{3}$ progeny tests of 27 randomly selected fertile $\mathrm{F}_{2}$ segregants of common bean from plot 0-685, where segregation is expected for male-fertile and male-sterile plants.

\begin{tabular}{|c|c|c|c|}
\hline Classification & $\begin{array}{c}\text { No. } \\
\text { in class }\end{array}$ & $\begin{array}{l}\mathrm{R} \text { a t } \mathrm{i} \boldsymbol{Q}^{2} \\
\text { tested value }\end{array}$ & $P$ value \\
\hline $\begin{array}{l}\mathrm{F}_{3} \text { progeny } \\
\text { Segregating } \\
\text { Nonsegregating }\end{array}$ & $\begin{array}{r}20 \\
\lg 7\end{array}$ & $2: 1 \quad 0.667$ & 0.41 \\
\hline $\begin{array}{l}\text { Phenotypic }^{2} \\
\text { Fertile } \\
\text { Sterile }\end{array}$ & $\begin{array}{l}58.5 \\
184\end{array}$ & $3: 1 \quad 0.472$ & 0.49 \\
\hline
\end{tabular}

${ }^{2}$ Combined data from the $\mathrm{F}_{3}$ progenies that segregated for male-sterile plants. 
moved and data were taken on the number of plants with mature pods (fertile plants) and the number of plants that were still flowering and had set no pods (sterile plants).

We hypothesize that the selection labeled MS-3 is a male-sterile mutant that produced a few seeds by means of insect-mediated openpollination. The two plants produced from seeds of MS-3 appeared to be completely normal with respect to pollen shed, pod set, and pod fill, although no quantitative data were taken. The seeds harvested from those two plants were hypothesized to be $\mathrm{F}_{2}$. In plots $0-684$ and $0-685$, flowers were examined on plants that failed to set pods after 2 weeks of flowering, and those flowers invariably had shriveled anthers that failed to shed any pollen. The observed segregation in plots $0-684$ and $0-685$ fit a $3: 1$ ratio for fertile to sterile plants (Table 1). The data support the hypothesis that the failure of pollen shed was controlled by a single recessive gene, for which we propose the symbol $m s-1$. The hypothesis is further supported by the fact that manual cross-pollination of barren plants resulted in well-filled pods. The barrenness cannot be due to infertility of the ovules, but must be due to the failure of pollen shed associated with the observation of shriveled anthers. None of the male-sterile plants set any pods, i.e., the sterility was complete under those field conditions.

The hypothesis was further tested in a backcross that gave a satisfactory fit to an expected 1:1 segregation ratio of fertile to male-sterile plants (Table 2). None of the male-sterile segregants set pods.

The segregation in the $\mathrm{BC}_{1}-\mathrm{F}_{2}$ test gave a good fit to a 3:1 ratio for fertile and sterile (Table 2). Similarly, the $\mathrm{F}_{3}$ progeny tests showed a good fit to the expected 2:1 ratio of segregating to nonsegregating progenies (Table 3). All the $27 \mathrm{~F}_{3}$ plots gave a satisfactory fit to a 3:1 ratio of fertile to sterile plants (data not shown). When the data for all 27 plots were combined, they gave a good fit to a 3:1 ratio of fertile to sterile plants (Table 3 ). These results confirm the hypoth- esis that the male sterility mutation found in plant MS-3 was controlled by a single recessive gene.

The question remains whether the MS-3 mutation might be a new mutant very close to the $s b$ locus and allelic to the male sterility in $s b^{\mathrm{ms}}$. Because plants with the genes $s b^{\mathrm{ms}}$ and $m s-1$ cannot be crossed with each other in their homozygous state, the best alternative was to cross one mutant in the fertile heterozygous state onto the other mutant homozygote. This creates the expectation of a 1:1 $\mathrm{F}_{1}$ segregation (fertile to sterile) if the genes are allelic and an all-fertile $F_{1}$ population if they are not allelic. All $43 \mathrm{~F}_{1}$ plants from the allelism test cross $s b^{\mathrm{ms}} \times M s-1 / m s-1$ were fertile. Thus, $m s-1$ must be nonallelic with $s b^{\mathrm{ms}}$.

The $s b^{\mathrm{ms}}$ mutant is superior to $m s-1$ for use in various recurrent selection schemes, because the spindly branch marker character allows the breeder to enter the field at full plant senescence and select the male-sterile segregants without having to identify steriles previously by examination of flowers from each plant in the field. That advantage holds where there are abundant insect vectors for the pollen. However, the unmarked malesterile gene is preferable where the insect vectors are insufficient to achieve full pod set on male-sterile plants. In that situation, the male-sterile segregants can be distinguished easily from fertile segregants during the fifth week after the onset of flowering because the fertile segregants will be yellowing due to senescence, whereas the malesterile plants with partial pod set will be green. The spindly branch marker should be avoided unless it provides a useful advantage, because plants with normal branch formation provide easier cultural management.

Further, $m-1$ can be used to facilitate backcross test studies. Common bean is a self-pollinated crop that requires emasculation to obtain hybrid seed. Depending on genotype, one usually obtains from four to six seeds per pollination. This low seed yield per pollination discourages backcross tests.
There is also the hazard of obtaining a few selfed seeds from imperfect emasculation. The problem is rarely one of leaving behind an anther, but rather one of an anther bursting and shedding a few pollen grains before (or during) emasculation. Examination of the stigmatic surface with a $\times 25-30$ hand lens after emasculation can minimize, but not eliminate, the problem. Choosing the most mature flower buds for emasculation maximizes the chances for pod set, but also increases the problems of partial pollen shed.

By combining the $m s-1$ allele with the recessive genotype to be used in the backcross test, three important advantages are obtained. First, crossing onto a plant with $\mathrm{ms}$ -

$1 / m s-1$ completely eliminates the problem of accidental selfs contaminating the backcross test population. Second, the crosses are made on fully opened flowers without any need for emasculation, which saves much time and labor. Third, the inherent genetic advantages of a backcross test over an $\mathrm{F}_{2}$ test are gained. For example, where two or more unlinked genes are involved in complex interactions, it is much more efficient to use the $\mathrm{BC}_{1}-\mathrm{F}_{1}$ and $\mathrm{BC}_{1}-\mathrm{F}_{2}$ generations than the $\mathrm{F}_{2}$ and $\mathrm{F}_{3}$ generations for genetic analysis.

\section{Literature Cited}

Ashraf, M. and M.J. Bassett. 1986. Cytogenetic analysis of translocation heterozygosity in the common bean (Phaseolus vulgaris L.). Can. J. Genet. Cytol. 28:574-580.

Bassett, M.J. 1989. List of genes. Annu. Rpt. Bean Improv. Coop. 32:1-15.

Bassett, M.J. 1990. Three mimic mutants for spindly branch in common bean and tests for linkage with other mutants. HortScience 25:1280-1281.

Bassett, M.J. 1991. A pleiotropic mutant for male sterility and spindly branching at the $s b$ locus in common bean. J. Amer. Soc. Hort. Sci. 116:346-348

Mutschler, M.A. and F.A. Bliss. 1980. Genie male sterility in the common bean (Phaseolus vulgaris). J. Amer. Soc. Hort. Sci. 105:202-205.

Wyatt, J.E. 1984. Inheritance of an indehiscent anther character in common bean. HortScience 19:670-671. 